researchers, mostly from developing countries, who collected information, held meetings, and commissioned special papers over three years. The report contains the all too familiar description of the inequalities of health between and within countries, but what is more striking and less familiar is the inequity of the distribution for funding of research both between and within countries. Most assistance (79\%) with all forms of development is bilateral, directly from one country to another, but only $5 \%$ of this is targeted on health services. The worldwide investment in health research is $\$ 30 \mathrm{bn}$, but only $5 \%$ of this is spent on health problems of developing countries, where $93 \%$ of the years of potential life are lost. How does the commission aim to rectify the situation?

It recommends a programme of essential national health research for each developing country, addressing both problems specific to each country and global problems. International partnerships need to be strengthened and new ones forged to help the programme, for which funds must be found. The commission recommends that at least $2 \%$ of national health expenditure should be invested in the programme and that at least $5 \%$ of all grants should go to research. These recommendations follow a strong argument for the value of health research as an important long term investment in development. The committee points out that this investment appreciates over time, whereas many short term aid programmes depreciate.

It is difficult to argue with the logic and conclusions. The report, however, is brief, presumably to maximise readership, and therefore leaves some concerns about the method of achieving the aims. A key element for Lamin was the fact that the community identified a health problem and asked for help. If research specific to a country is to be successful this will be crucial to its success. How will this be done? Most of the communities in Africa still see ill health in terms of spirits or witchcraft, a perception at odds with Western models. Most of the doctors in these countries have been brought up to subscribe to the Western model of health and to reject the community's view. Can this be reconciled to produce research specific to a country that is based on real community needs? Current success in scientific research is measured in publications. Will international peer reviewed journals consider this form of locally relevant research suitable? Will research workers be happy to embark on work that may be published, and recognised, only locally?

This all assumes that there are some local health research workers available. Lamin may have to give up research in the near future to earn money in private practice. It is all too familiar: government employees in developing countries cannot afford to do research because they are overburdened with routine duties and their spare time is needed to generate income. Will international and bilateral aid organisations be persuaded to underwrite research workers' careers in the long term? Can this be done without undermining purely clinical workers? Perhaps governments need to consider paying supplements to promising researchers to give them the time to pursue their ideas. Indeed, the similarity of the commission's recommendations to the Brandt report reminds one of the question, "When will the crumbs fall from Brandt's table?"

It seems that the commission is already addressing implementation of its recommendations. A task force has been set up to coordinate fund raising, and the World Health Organisation has taken up one of the points raised by the commission in starting a new programme on tuberculosis. Let's hope that Lamin gets something out of all this.

ANDREW J HALL

Senior Lecturer,

Communicable Disease Epidemiology Unit,

London School of Hygiene and Tropical Medicine,

London WC1E 7HT

1 Commission on Health Research for Development. Health research: essential link to equity in development. Oxford: Oxford University Press, 1990

\title{
Doctors and the European Community
}

\section{The agenda lengthens}

The completion of the European single market at the end of 1992 may change many aspects of economic and social life in Britain, but a single market for doctors has existed almost unnoticed since 1977. Medical directives which became effective in that year entitled doctors who are European Community nationals and who hold primary medical qualifications awarded in a member state of the community to practise in any member state. The completion of the single market will not change this.

Despite alarmist predictions implementation of the medical directives did not lead to a massive influx into Britain of doctors from other European Community countries, and the number migrating remained low for almost a decade. Recently the situation has been changing rapidly, and over 1000 practitioners from other European Community countries have been registered by the General Medical Council in each of the past two years. Though most of these doctors intend to return to their countries of origin after a period of training, a recent survey by the Department of Health suggested that almost a fifth are seeking permanent careers in Britain.

The directives require member states to recognise the basic and specialist medical qualifications awarded by other member states by giving them the same effect as they give to their own qualifications. All European Community nationals with basic medical qualifications from a European Community country are thus entitled to full registration with the General Medical Council, without having completed an internship year if their national regulations do not require one. The position regarding specialist qualifications has been widely misunderstood. The title of specialist is not protected in Britain, and any doctor may legally describe himself or herself as a specialist. There is thus no effect to be given to a specialist diploma acquired in another European Community country. General practice is different: doctors who have completed the two year vocational training prescribed in the general practitioner's directive have a right to establish themselves as general practitioner principals in Britain. Intense competition for positions in general practice has, however, prevented any substantial migration of trained general practitioners.

The Treaty of Rome, to which Britain acceded in 1973, established a market in which goods, people, services, and capital could circulate freely. It did not aim at a political or monetary union and did not deal with health and social affairs except in so far as they were relevant to a free market. The structure of the European Commission reflects the original aims of the community and does not include a directorate for 
health affairs, but many aspects of the commission's work impinge on health.

This has necessitated the development of representative European medical organisations, usually from a coming together of national associations or specialty groups. These bodies communicate with the European Commission through the Standing Committee of Doctors of the European Community. The standing committee's agenda is wide ranging, recent meetings having considered regulating access to medical studies, specialist training, quality assurance in health care, product liability, regulating pharmaceuticals, ethical issues (AIDS, transplantation, and genome analysis), care of the elderly, and informatics in medicine. Some of these have been debated for 20 years without resolution. A working party has recently proposed ways of making the standing committee more effective.

The fragmented and partial involvement of the European Community in health matters is, however, largely responsible for the slow progress. The existence of substantial unemployment among doctors in the European Community (perhaps over 100000 doctors) and the inability of some states to regulate access to medical studies for legal reasons have distorted the market for doctors and jeopardised standards of training. The commission has shown little understanding of this problem and no readiness to act. Standards of medical training, both basic and specialist, vary greatly between member states, but again, despite a succession of reports from the commission's advisory committee on medical training (a body made up of doctors), no attempt to tighten the minimal provisions set out in the medical directives has been made. Last year the BMA's annual representative meeting reaffirmed its support for a new directive on numbers of medical students and for adopting stricter controls on standards of training. The association's European Communities committee will be pursuing these policies in discussions with the Department of Health this year, but rapid progress seems unlikely without a restructuring of the European Commission and the creation of a health directorate, something which is not even under consideration at present.

Increasing medical migration does, however, raise several issues for consideration at a national level. Trainers who are responsible for doctors who have qualified in other European Community countries need to be aware of the different educational systems in the various countries. In particular, few continental medical schools provide as much clinical teaching as is usual in Britain, and trainees from the European Community may need some coaching in clinical skills at the beginning of their appointments. Occasionally, a trainer may doubt the adequacy of a doctor's basic training. The BMA and the General Medical Council both have a role in monitoring standards of training in Europe but need to be made aware of trainers' anxieties if they are to fulfil it.

Freedom of migration within the European Community offers an opportunity for closer contact and valuable cross fertilisation of ideas between doctors in different countries, and it is desirable that the traffic should be two way. Several schemes exist to help British doctors wishing to train in other European Community countries, and these should be encouraged. At the same time, there is concern that training opportunities for European Community doctors in Britain are unnecessarily restricted by their ineligibility for visiting registrar posts and the requirement for them to compete for career registrar posts, even though most do not intend to make a permanent career here. A third category of registrar post needs to be devised that would cater for European Community trainees without destroying the principles underlying Achieving a Balance.

Although 1992 will not bring with it any new regulations directly affecting doctors, important decisions on matters affecting health care are increasingly being taken in Brussels. The BMA and the medical profession generally need to be aware of this and to respond accordingly. The recent decision by the BMA council to spend $£ 12500$ of the association's funds to establish a permanent secretariat in Brussels for the Standing Committee of Doctors of the European Community is encouraging. ' Recent moves to strengthen the association's international affairs division must continue, and inevitably more staff will have to be committed full time to monitoring and organising events and lobbying in Europe. The medical profession in Britain could have an important role in shaping European medicine in the twenty first century, but it will succeed in doing so only by developing the necessary awareness and commitment.

STEPHEN BREARLEY

Senior Surgical Registrar,

United Kingdom Representative,

Permanent Working Group of European Junior Hospital Doctors,

Queen Elizabeth Hospital,

Birmingham B15 2TH

DOUGLAS GENTLEMAN

Neurosurgical Senior Registrar,

(Formerly Coordinating Secretary,

Permanent Working Group of European Junior Hospital Doctors)

Institute of Neurological Sciences,

Southern General Hospital,

Glasgow G51 4TF

1 Richards T. Edging into Europe. BMF 1991;302:1173

\section{Genetics and lung disease}

\section{Advances our understanding of emphysema, cystic fibrosis, and asthma}

The delicate structure of the lung is frequently exposed to inhaled environmental insults. The body has an array of defences against them, including the mucociliary escalator of the bronchi, the scavenging macrophages of the alveolus, and the mechanisms for developing immunity, mediated by $\mathrm{T}$ and $B$ lymphocytes. Disease ensues if environmental insults overwhelm initial barriers, when inflammatory pathways and the specific immune response may contribute to tissue damage. Infections of the lung have an enormous impact on mortality and morbidity worldwide, organic dusts can "drive" bronchial disease such as asthma or alveolar disease, inorganic dusts produce the pneumoconioses, and cigarette smoke destroys lung tissue (emphysema) and causes lung cancer. Previously overshadowed, the role of genetic factors in lung disease is now becoming more evident with changing patterns of disease and as a result of the molecular genetic "revolution." Such developments are offering improved understanding of emphysema, cystic fibrosis, and asthma and also hopes for their more effective treatment and prevention.

Though most cases of emphysema are attributable to the overwhelming effects of heavy cigarette smoking, one distinct group of patients is unduly susceptible to the destructive 